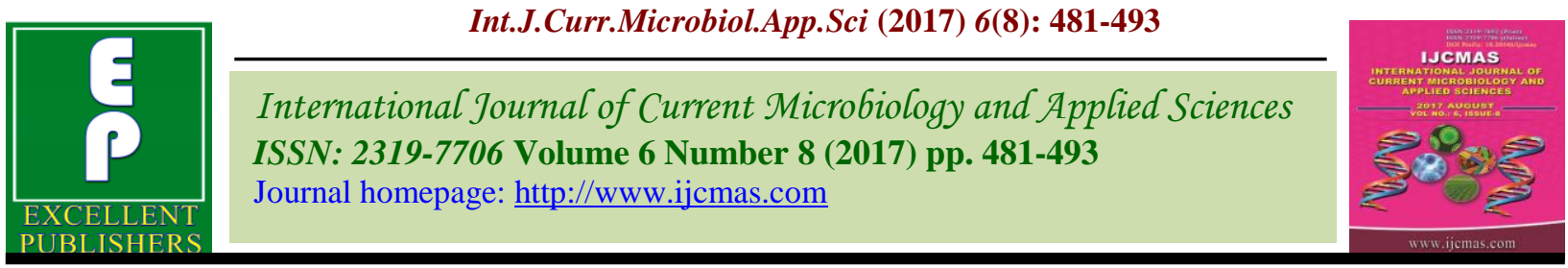

Original Research Article

https://doi.org/10.20546/ijcmas.2017.608.063

\title{
Flowering and Production Improvement Studies of Mango cv. Banganpalli in Relation to Plant Growth Regulators and Chemicals
}

\author{
Golla Vijay Krishna ${ }^{1}$, A. Bhagwa ${ }^{2}$, M. Raj Kumar ${ }^{2}$ and A. Siva Shankar ${ }^{3}$ \\ ${ }^{1}$ College of Horticulture, Rajendranagar, Hyderabad -500030, Telangana, India \\ ${ }^{2}$ Fruit Research Station, Sangareddy, Medak- 502001, Telangana, India \\ ${ }^{3}$ Department of crop Physiology, College of Agriculture, Rajendranagar, Hyderabad -500030, \\ Telangana, India \\ *Corresponding author
}

\section{A B S T R A C T}

\begin{tabular}{|l|}
\hline Ke y w or d s \\
Spermine, \\
Spermidine, \\
Flower enhancing \\
plant growth \\
regulators, Mango. \\
\hline Article Info \\
\hline $\begin{array}{l}\text { Accepted: } \\
\text { 04 June } 2017 \\
\text { Available Online: } \\
\text { 10 August } 2017\end{array}$ \\
\hline \hline
\end{tabular}

The present investigation was conducted during 2011-12 at Fruit research station, Sangareddy to study the influence of flower enhancing plant growth regulators and fruit set improving chemicals on mango cv. Banganpalli. Trees applied with paclobutrazol $\left(3 \mathrm{ml} . \mathrm{m}^{-1}\right.$ of canopy diameter) alone significantly increases percent flowering (25\% over control), panicle length and breadth at the time off full bloom stage. Significantly the highest fruits per panicle and yield were recorded in paclobutrazol (42.17\% over control) alone applied trees compare to control. Boron $\left(1.25 \mathrm{gr} . \mathrm{l}^{-1}\right)$ could able to significantly increase the fruit per panicle and final retention of fruits and increased the fruit weight reflecting in the overall increase in yield by 37 percent. Among the combination, maximum increase in yield over control was recorded in paclobutrazol application along with spermidine at $0.01 \mathrm{mM}(63.11$ $\%)$, NAA at $80 \mathrm{ppm}+$ spermidine at $0.01 \mathrm{mM}(57.59 \%)$, NAA at $80 \mathrm{ppm}+$ boron at $1.25 \mathrm{gr} . \mathrm{l}^{-1}(60.03 \%)$. However, based on benefit cost ratio spraying of NAA + Boron has give maximum benefit cost ratio of 3.06. Among the fruit set improving chemical boron either alone or in combination with NAA has recorded highest improvement in the yield.

\section{Introduction}

Mango (Mangifera indica) is the premier fruit among the tropical fruits and has been in cultivation in the Indian subcontinent since several centuries. Mango occupied an area of 2.312 million hectares with a production of 15.026 million tonnes (NHB Database, 2011). The fruit is highly valued because of its excellent flavor, appealing aroma, delicious taste, attractive shades of colour and nutritive value, which has attracted the world market. In India, Andhra Pradesh is the leading mango producing state and occupies an area of 0.48 million hectares with a production of
4.05 million tonnes (NHB Database, 2011). Although, India is the leading mango producing country, the development of mango orchards as an established industry has remained a distant goal and the per hectare yields $\left(2.45 \mathrm{t} \mathrm{ha}^{-1}\right)$ are low in spite of great potential (NHB Database, 2011).

There are several reasons for poor productivity in mango cv. Banganpalli in Andhra Pradesh. Among them, poor and erratic flowering coupled with poor or nil fruit set in mango cv. Banganpalli is one of 
the major reasons for poor productivity. The climatic changes especially temperature during flowering and fruit set period has been attributed to erratic flowering and poor fruit set in mango cv. Banganpalli (Bhagwan et al., 2011). Modulation of flowering and fruit set by spraying of various hormones and chemicals is the best alternative to mitigate or reduce the climate change effect on mango. Various chemicals and plant growth regulators application have been standardized for enhancing and uniform flowering in mango. Application of paclobutrazol @ $3 \mathrm{ml} . \mathrm{m}^{-1}$ canopy diameter was found to improve the flowering about 38\% in mango cv. Banganpalli (Bhagwan et al., 2011). The effect of paclobutrazol in improving flowering percent was due to its anti gibberellins activity (Quinlin and Richardson, 1984). Spraying of NAA @ of 50-100 ppm has shown the effect in early flowering (Davenport, 2007) in mango. Naphthalene acetic acid (NAA), an auxin group of plant growth regulator was found to have an effect on the flower promoting activity in mango (Beyer, 1976).

Polyamines form a class of aliphatic amines that are ubiquitous in living organisms and are known to have role in a wide range of biological processes including plant growth and development (Pandey et al., 2000). Putrescine, spermidine and spermine are the major forms of polyamines which are biosynthesised from orginine or ornithine. Polyamines arise from a common metabolic intermediate pathway as of ethylene and are believed to act antagonistically to ethylene in several physiological process like stress, senescence etc. (Anonymous, 2004). Recently, polyamines have been attributed to play a role in the fruit set of many crop including mango (Aman ullah Malik and Zora Singh, 2006). Among the micronutrients, spraying of Boron at full bloom stage has significantly improved fruit set in mango
(Zong Runi and Dong, 2000) by enhancing the pollen grain germination and pollen tube elongation which consequently leads to better fruit set (Saleh and El-Monem, 2003).

However, no work has been carried out on the combination of both flower enhancing plant growth regulators and fruit set improving chemicals on yield of mango cv. Banganpalli along with cost benefit ratio for successful commercialization of these plant growth regulators and chemicals.

\section{Materials and Methods}

The experiment was carried out during 201112 at Fruit Research Station Sangareddy, Medak district, Dr. YSRHU, A.P. Fifteen years old, well grown, uniform statured trees of mango cv. Banganpalli were selected for the experiment. Trees were spaced with $8 \mathrm{~m}$ and planted in square system. Paclobutrazol concentration was calculated based on the diameter of the tree, and applied @ 3 ml.m-1 of canopy diameter. The required paclobutrazol was dissolved in 10 litre of water, applied as soil drench 120 days before bud break (Bhagwan et al., 2011). $75 \mathrm{mg}$ of NAA was dissolved in $50 \mathrm{ml}$ of ethanol and diluted it in 1 litres of water to get $80 \mathrm{ppm}$ of NAA, Sprayed 30 days before flowering (Davenport, 2003). $1.45 \mathrm{mg}$ of spermidine was dissolved in 1 litre of water to get 0.01 $\mathrm{mM}$ of spermidine. $20 \mathrm{mg}$ of spermine was dissolved in 1 litre of water to get $0.1 \mathrm{mM}$ of spermine. $1.25 \mathrm{gm}$ of boron $(20 \%)$ was dissolved in 1 litre of water to get $1.25 \mathrm{~g} . \mathrm{l}^{-1}$ of boron. Fruit set improving chemicals (spermidine, spermine and boron) were sprayed at full bloom stage.

The statistical design adopted was Factorial Randomised block design with 12 treatments which were replicated thrice. For recording flowering, fruit set and yield parameters, 40 well distributed healthy shoots were tagged in 
four directions of plant canopy. Data on percent flowering (\%), panicle length and breadth, No. of days taken for fruit set from panicle initiation, fruit set per panicle, fruit weight, yield and cost benefit ratio were recorded. The data were subjected to statistical analysis as per the procedure out lined by Panse and Sukhatme (1985).

\section{Results and Discussion}

The changes in percent flowering (\%) of mango cv. Banganpalli sprayed with different flower enhancing plant growth regulators and fruit set improving chemicals are presented in table 1. At initial stage of flowering (Dec 20th) maximum flowering percent recorded in application of Paclobutrazol $\left(\mathrm{P}_{1}\right)$ (14.22), which was on par with application of NAA $\left(\mathrm{P}_{2}\right)$ (11.72). Minimum flowering percent was recorded in untreated control $\left(\mathrm{P}_{0}\right)$ (7.32). At 20 days after initial stage of percent flowering (Jan 10th) Maximum flowering percent recorded in application of paclobutrazol $\left(\mathrm{P}_{1}\right)$ (54.99). Minimum flowering percent was recorded in untreated control $\left(\mathrm{P}_{0}\right)$ (43.56), which were on par with application of NAA $\left(\mathrm{P}_{2}\right)$ (45.78). There was no significant difference observed among flower enhancing plant growth regulator application with respect to percent flowering at 40 days after initial stage of percent flowering (Feb 1st). Paclobutrazol was significantly more effective in increasing the flowering percentage. Gibberellins, a group of plant growth hormones were reported to be inhibitory to flowering (Kachru et al., 1971), in mango and the available evidence suggests the flower promotive effect of paclobutrazol in mango due to its anti - gibberellin activity (Quinlan and Richardson, 1984). Hence, in the present investigation the increase in the percent (\%) flowering of mango by paclobutrazol was due to its anti - gibberellin activity. The similar findings of increase in per cent flowering (\%) by application of PBZ was earlier reported by Kumar Raj et al., (2005) in mango cv. Baneshan, Orwintiner et al., (2008) and Muhammad Nafeez et al., (2010) in mango cv. Irwin. NAA spray has also significantly increased the flowering in mango cv. Banganpalli in the present investigation when compared with the control. Similar increase in flowering with spraying of NAA was reported in mango cv. Succary Abiad (Wahdan et al., 2011). NAA which is considered as flowering hormones in some crops (Moti-Singh et al., 1987) might have increased the latent flowering factors in the mango and resulted in overall increase in flowering in mango cv. Banganpalli when compared to control in the present investigation.

The data (Tables 2 and 3) indicating that there is significant difference among flower enhancing plant growth regulators with respect to panicle length and breadth. Minimum panicle length was recorded in untreated control $\left(\mathrm{P}_{0}\right)$ (14.79), which was on par with spraying of NAA $\left(\mathrm{P}_{2}\right)$ (15.86). Maximum panicle length was recorded in application of paclobutrazol $\left(\mathrm{P}_{1}\right)$ (16.64). Among interactions minimum panicle length was recorded in control $\left(\mathrm{P}_{0} \mathrm{~F}_{0}\right)(12.63)$, which was on par with spraying of spermidine alone $\left(\mathrm{P}_{0} \mathrm{~F}_{1}\right)$ (13.76), paclobutrazol along with boron application $\left(\mathrm{P}_{1} \mathrm{~F}_{3}\right)(14.40)$ and NAA along with boron application $\left(\mathrm{P}_{2} \mathrm{~F}_{3}\right)(15.33)$. Maximum length was recorded in Paclobutrazol alone application $\left(\mathrm{P}_{1} \mathrm{~F}_{0}\right)$ (17.73). Minimum panicle breadth was recorded in application of NAA $\left(\mathrm{P}_{2}\right)(10.65)$, which was on par with untreated control $\left(\mathrm{P}_{0}\right)$ (10.93). Maximum panicle breadth was recorded in application of paclobutrazol $\left(\mathrm{P}_{1}\right)$ (12.31). Among interaction minimum panicle breadth was recorded in spraying of spermidine alone $\left(\mathrm{P}_{0} \mathrm{~F}_{1}\right)$ (9.36), which was on par with application of NAA along with spermidine $\left(\mathrm{P}_{2} \mathrm{~F}_{1}\right)$ (9.86), NAA along with boron application $\left(\mathrm{P}_{2} \mathrm{~F}_{3}\right)$ (9.93) and control 
$\left(\mathrm{P}_{0} \mathrm{~F}_{0}\right)$ (10.23). Maximum panicle breadth was recorded in application of paclobutrazol alone $\left(\mathrm{P}_{1} \mathrm{~F}_{0}\right)$ (13.10). Similar increase in panicle length with the application of paclobutrazol in mango was reported by Vijayalaxmi and Srinivasan (1998) in mango cv. Alphonso when trees treated with PBZ @ $10 \mathrm{ml}^{\text {.tree }}{ }^{-1}$. Paclobutrazol could able to increase the panicle breadth compare to control and NAA (Table 3). However, Winston (1992) in mango cv. Kensington and Orwintinll et al., (2008) in mango cv. Irwin reported that the panicles of paclobutrazol treated trees were considerably shorter than those of control trees. The discrepancy in the finding of present investigation to the earlier reports regarding panicle may be due to varietal change, time of applications and dosage of paclobutrazol. However, increase in panicle length and breadth of paclobutrazol treated trees might be beneficial for increase the number of hermaphrodite flowers per panicle. This may cause for better fruit set over the control.

Fruit set improving chemical treatments have been sprayed during flowering and hence, it might not have influenced on the percent flowering, panicle length and breadth which were recorded before flowering or at full bloom stage. However, any significant differences in flowering might have resulted from the factors other than fruit set improving chemical which were sprayed after the data on flowering parameters has been recorded.

The results on number of days taken for fruit set after panicle initiation after application of different flower enhancing plant growth regulators and fruit set improving chemicals are presented in the table 4. Among fruit set improving plant growth regulators minimum number of days was recorded in untreated control $\left(\mathrm{P}_{0}\right)$ (49.66), followed by NAA $\left(\mathrm{P}_{2}\right)$ (54.83). Maximum number of days was recorded in application of paclobutrazol $\left(\mathrm{P}_{1}\right)$
(58.83). Paclobutrazol could not able to reduce the time taken for fruit set after panicle initiation compare to control. However, increase in days taken for fruit set from panicle initiation might be beneficial for better fruit set and fruit retention in paclobutrazol treated trees. Fruit set improving chemical treatments did not differ significantly on number of days taken for fruit set after panicle initiation of mango. Significant difference was observed in interaction effect between flower enhancing plant growth regulators and fruit set improving chemicals with respect to number of days taken for fruit set after panicle initiation of mango. Minimum number of days was recorded in spraying of spermidine alone $\left(\mathrm{P}_{0} \mathrm{~F}_{1}\right)$ (45.66), which was on par with control $\left(\mathrm{P}_{0} \mathrm{~F}_{0}\right)$ (46.33), NAA along with spermine application $\left(\mathrm{P}_{2} \mathrm{~F}_{2}\right) \quad$ (48.33). Maximum number of days was recorded in Paclobutrazol alone application $\left(\mathrm{P}_{1} \mathrm{~F}_{0}\right)$ (62.00). This increase in days may be due to increase in days taken for full bloom stage. However, these may further cause for better fruit set by providing prolonged pollination period by the effect of polyamines (Crisosto et al., 1988).

The data presented in table 5 indicating that maximum fruit set per panicle was recorded in application of paclobutrazol $\left(\mathrm{P}_{1}\right)(5.95)$, followed by application of NAA $\left(\mathrm{P}_{2}\right)$ (5.61).Minimum fruit set per panicle observed in untreated control $\left(\mathrm{P}_{0}\right)$ (5.36) Similar increase in fruit set per panicle in response to paclobutrazol application was recorded by Kumar Raj et al., (2005) in cv. Baneshan and Orwintinee et al., (2008) in mango cv. Irwin. Among fruit set improving chemical treatments maximum fruit set per panicle was recorded in application of boron $\left(\mathrm{F}_{3}\right)$ (6.04), followed by spermidine $\left(\mathrm{F}_{1}\right)(5.64)$, which was on par with untreated control $\left(\mathrm{F}_{0}\right)(5.62)$. Minimum fruit set per panicle was recorded in spermine $\left(\mathrm{F}_{2}\right)$ (5.26). Similar increase in fruit 
set was earlier obtained by Sanna et al., (2005) in mango cv. Fagri kalan when trees were sprayed with boron and Ramzy et al., (2011) in mango. Boron is essential for stigma receptivity and pollen tube extension by formation of boron sorbitol (carbohydrate) complex that promotes absorption, translocation and metabolism of sugar in pollen and synthesis of pectin material for cell wall of growing pollen tube (Nyomora and Brown, 1997). Among interaction effect between flower enhancing plant growth regulators and fruit set improving chemicals maximum fruit set per panicle was recorded in application of paclobutrazol along with boron $\left(\mathrm{P}_{1} \mathrm{~F}_{3}\right)$ (6.40). Minimum fruit set per panicle was recorded in control $\left(\mathrm{P}_{0} \mathrm{~F}_{0}\right)(4.86)$. Paclobutrazol could able to increase fruit set per panicle compared to control and NAA (Table 5). This may be due to increase of number of perfect flowers per panicle. Paclobutrazol combination with spermidine could able to increase fruit set per panicle significantly when compared to control (Table 5). Paclobutrazol could helps in getting more number of perfect flowers and thus further helps in better fruit set in paclobutrazol treated trees compare to control (Kumar Raj et al., 2005).

Polyamines like spermidine may increase the fruit set per panicle by improving embryo development (Ponce et al., 2002), increase viability of the ovule and prolonged pollination period (Crisosto et al., 1988) there by increasing the pollen germination and pollen tube growth (Wolukan et al., 2004). Paclobutrazol along with spermidine because of their fruit set improving properties, might have caused increase in number of fruits per panicle synergistically compare to their individual application and control. The similar synergistic effect in increasing the number of fruits per panicle was earlier reported by Kumar Raj et al., (2005). Combination of paclobutrazol along with $\mathrm{Ca}$
$\left(\mathrm{NO}_{3}\right)_{2}$ increases number of fruits per panicle compares to their individual application in mango cv. Baneshan.

The changes in fruit weight (gm) of mango cv. Banganpalli sprayed with different flower enhancing plant growth regulators and fruit set improving chemicals are presented in the table 6. Among flower enhancing plant growth regulators maximum weight was recorded in application of NAA $\left(\mathrm{P}_{2}\right)$ (302.08). Minimum fruit weight was recorded in untreated control $\left(\mathrm{P}_{0}\right)$ (269.74), which was on par with application of paclobutrazol $\left(\mathrm{P}_{1}\right)$ (289.74). Similar increase in fruit weight was earlier reported by Wahdan et al., (2011) in mango cv. Succary Abiad treated with NAA @ 60 ppm. Among fruit set improving chemicals maximum fruit weight was recorded in application of Boron $\left(\mathrm{F}_{3}\right)$ (302.88). Minimum fruit weight was recorded in untreated control $\left(\mathrm{F}_{0}\right)(266.88)$, which were on par with application of spermine $\left(\mathrm{F}_{2}\right)$ (290.00) and spermidine $\left(\mathrm{F}_{1}\right)$ (289.00). In the early stages of fruit development the polyamines are maintained at a high level, followed by decline with fruit development in mango (Malik and Singh, 2004), Grape (Shiozaki et al., 2000). The high polyamine concentrations may be related to the high growth rate at initial stages of fruit development (Fraga et al., 2004) in prunus persica or active cell division (Galston, 1983). These high growth rate and active cell division at initial stages of fruit development might be cause for in fruit weight. Similar increase in fruit weight in Canino Apricot was earlier obtained by Enas et al., (2010) treated with polyamine. Among the interaction effect maximum fruit weight was recorded in application of NAA along with boron $\left(\mathrm{P}_{2} \mathrm{~F}_{3}\right)$ (331.66). Minimum fruit weight was recorded in spraying of spermidine alone $\left(\mathrm{P}_{0} \mathrm{~F}_{1}\right)$ (239.00). NAA might have increased the fruit weight by increasing the fruit pulp content and fruit size. The similar increase in fruit 
weight by Boron application was earlier reported by Ramzy et al., (2011) in mango. In the interaction of NAA along with boron because of their both fruit weight improving properties, might have caused for increase in fruit weight synergistically compare to their individual application and control. The similar synergistic effects in increasing the fruit weight were earlier reported by Sanna et $a l$. , (2005) with sucrose along with boric acid increase fruit weight synergistically in combination compare to individual application.

The presented in table 7 revealed that there is significant difference in yield (kg.tree-1) among different flower enhancing plant growth regulators. Maximum yield was recorded in application of paclobutrazol $\left(\mathrm{P}_{1}\right)$ (43.03), which was on par with application of NAA $\left(\mathrm{P}_{2}\right)$ (40.75). Minimum yield was recorded in untreated control $\left(\mathrm{P}_{0}\right)$ (35.33). The increased in intensity of flowering, better fruit set and fruit weight in paclobutrazol treated trees have ultimately increased the yield of mango by $42.17 \%$. Burondkar and Gunjate (1993) have also found similar correlation between flowering, fruit set, fruit weight and yield of mango in response to paclobutrazol application. Similar increased in yield of mango in response to paclobutrazol application was obtained by various worker like Kumbhar et al., (2007) in cv. Kesar and Orwintinee et al., (2008) in cv. Irwin. Fruit set improving chemical treatments had significant influence on yield per tree of mango. Maximum yield was recorded in application of spermidine $\left(\mathrm{F}_{1}\right)$ (43.38) which was on par with application of boron $\left(\mathrm{F}_{3}\right)$ (42.77) and with spermine $\left(\mathrm{F}_{2}\right)$ (38.34).Minimum yield was recorded in untreated control $\left(\mathrm{F}_{0}\right)$ (34.32). This increase in yield may be due to increase in fruit set per panicle and increase in average fruit weight. The similar increase in yield was earlier reported by Sanna et al., (2005) with boron spray in mango, Ramzy et al., (2011) with boric acid application in mango, Aman Ullah malik and Zora Singh (2006) application with polyamines in mango cv. Kensington pride. Among the interactions maximum yield was recorded in application of paclobutrazol along with spermidine $\left(\mathrm{P}_{1} \mathrm{~F}_{1}\right)(50.24)$, which was on par with application of NAA along with boron $\left(\mathrm{P}_{2} \mathrm{~F}_{3}\right)$ (49.19), NAA along with spermidine spray $\left(\mathrm{P}_{2} \mathrm{~F}_{1}\right) \quad$ (48.54), application of paclobutrazol alone $\left(\mathrm{P}_{1} \mathrm{~F}_{0}\right)$ (43.79), spraying of boron alone $\left(\mathrm{P}_{0} \mathrm{~F}_{3}\right)$ (42.36) and paclobutrazol along with spermine application $\left(\mathrm{P}_{1} \mathrm{~F}_{2}\right)$ (41.36). Minimum yield was recorded in application of NAA alone $\left(\mathrm{P}_{2} \mathrm{~F}_{0}\right)(28.36)$ which was on par with control (30.80). Paclobutrazol helps in getting more number of reproductive shoots (Muhamad Nafes et al., (2010) and also increases the perfect flowers per panicle (Kumar Raj et al., 2005) in mango. Spermidine could able to help in increasing fruit set and fruit retention (Amanullah Malik and Zora Singh, 2006) in mango and also improves the average fruit weight (Eanas et al., (2010). In the interaction of paclobutrazol along with spermidine synergistically increase the yield (kg per tree) by flower enhancing nature of paclobutrazol and fruit set, fruit retention and fruit weight increasing behaviour of spermidine could helps synergistically in getting more yield per tree compare to their individual application and control. Similar synergistic effect on increasing the yield was earlier reported by Sanna et al., (2005) with sucrose along with potassium citrate.

The data (Table 8) revealed that there is significant difference between flower enhancing plant growth regulators, fruit set improving chemicals with respect to number of days taken from panicle initiation to harvesting. Minimum number of days taken from panicle initiation to harvesting was recorded in paclobutrazol $\left(\mathrm{P}_{1}\right)$ (117.58), which was on par with application of NAA 
$\left(\mathrm{P}_{2}\right)$ (119.07).Maximum days were recorded in untreated control $\left(\mathrm{P}_{0}\right)$ (124.74) among plant growth regulators. Similar findings were obtained by GoGuey (1990), Singh and Dhillon (1992) in mango treated with paclobutrazol.

Table.1 Effect of flower enhancing plant growth regulators and fruit set improving chemicals on per cent flowering (\%) of mango cv. Banganpalli

\begin{tabular}{|c|c|c|c|c|c|c|c|c|c|c|c|c|c|}
\hline Treatment & \multicolumn{4}{|c|}{ Flowering in \% } & \multicolumn{5}{|c|}{ Flowering in $\%$} & \multicolumn{4}{|c|}{ Flowering in $\%$} \\
\hline Days & \multicolumn{4}{|c|}{ Dec 20th } & \multicolumn{5}{|c|}{ Jan 10th } & \multicolumn{4}{|c|}{ Feb 1st } \\
\hline & $\mathbf{P}_{1}$ & $\mathbf{P}_{2}$ & $\mathbf{P}_{\mathbf{0}}$ & Mean & $\mathbf{P}_{1}$ & $\mathbf{P}_{2}$ & & & Mean & $\mathbf{P}_{1}$ & $\mathbf{P}_{2}$ & $\mathbf{P}_{\mathbf{0}}$ & Mean \\
\hline $\mathbf{F}_{1}$ & $10.4 \mathrm{a}$ & $12.3 b$ & $2.8 \mathrm{a}$ & 8.5 & $37.14 \mathrm{a}$ & $50.47 \mathrm{~b}$ & 29 & & $39.04 \mathbf{a}$ & $73.32 \mathrm{~b}$ & $79.04 b$ & $64.75 \mathrm{a}$ & $72.37 \mathbf{a}$ \\
\hline $\mathbf{F}_{2}$ & $16.1 \mathrm{~b}$ & $8.9 \mathrm{a}$ & $12.3 \mathrm{~b}$ & 12.43 & $49.52 b$ & $26.65 \mathrm{a}$ & 45 & & $40.62 \mathbf{a}$ & $80.95 b$ & $49.49 \mathrm{a}$ & $71.42 \mathrm{~b}$ & $67.28 \mathbf{a}$ \\
\hline $\mathbf{F}_{3}$ & $15.2 \mathrm{~b}$ & $8.6 \mathrm{a}$ & $12.3 \mathrm{~b}$ & 12.03 & $62.84 \mathrm{~b}$ & $42.85 \mathrm{a}$ & 60 & & $55.54 \mathrm{~b}$ & $86.66 \mathrm{~b}$ & $75.23 \mathrm{~b}$ & $91.42 \mathrm{c}$ & $84.43 \mathbf{b}$ \\
\hline $\mathbf{F}_{0}$ & $15.2 \mathrm{~b}$ & $17.1 \mathrm{~b}$ & $1.9 \mathrm{a}$ & 11.4 & $70.47 \mathrm{c}$ & $63.18 b$ & 38. & & $57.24 \mathbf{b}$ & $88.56 b$ & $87.61 \mathrm{~b}$ & $75.23 b$ & $83.8 \mathbf{b}$ \\
\hline \multirow[t]{2}{*}{ Mean } & $14.22 \mathbf{b}$ & $11.72 \mathbf{b}$ & $7.32 \mathbf{a}$ & & $54.99 \mathbf{b}$ & $45.78 \mathbf{a}$ & 43. & & & 82.37 & 72.84 & 75.70 & \\
\hline & F-Test & S.Em \pm & \multicolumn{2}{|c|}{$\mathrm{CD}$ at $(5 \%)$} & F -Test & \multicolumn{2}{|c|}{ S.Em \pm} & \multicolumn{2}{|c|}{$\mathrm{CD}$ at $(5 \%)$} & F-Test & \multicolumn{2}{|c|}{ S.Em \pm} & CD at $(5 \%)$ \\
\hline Factor F & $*$ & 1.710 & \multicolumn{2}{|r|}{ NS } & $*$ & \multicolumn{2}{|c|}{3.577} & & 10.49 & $*$ & \multicolumn{2}{|c|}{3.494} & 10.25 \\
\hline Factor $\mathbf{P}$ & $*$ & 1.481 & & 4.343 & $*$ & \multicolumn{2}{|c|}{3.098} & & 9.08 & $*$ & \multicolumn{2}{|c|}{3.026} & NS \\
\hline $\mathbf{F} \times \mathbf{P}$ & $*$ & 2.962 & & 8.687 & $*$ & \multicolumn{2}{|c|}{6.196} & & 18.17 & $*$ & \multicolumn{2}{|c|}{6.052} & 17.75 \\
\hline
\end{tabular}

Figures with same alphabets did not differ significantly.

** Significant at $(\mathrm{p}=0.01$ LOS $), *$ Significant at $(\mathrm{p}=0.05$ LOS $), \quad$ NS- Non Significant.

Values were compared with respective C.D values.

$\mathrm{F}_{1}$ - Spermidine $0.01 \mathrm{mM}$

$\mathrm{F}_{2}$ - Spermine $0.1 \mathrm{mM}$

$\mathrm{F}_{3}$ - Boron 1.25g. $\mathrm{l}^{-1}$

$$
\begin{aligned}
& \mathrm{P}_{1}-\mathrm{PBZ} 3 \mathrm{ml} \cdot \mathrm{m}^{-1} \\
& \mathrm{P}_{2} \text { - NAA } 80 \mathrm{ppm} \\
& \mathrm{P}_{0} \text { - Control } \\
& \mathrm{F}_{0} \text { - Control }
\end{aligned}
$$

\begin{tabular}{|c|c|c|c|c|}
\hline \multirow{2}{*}{ Treatment } & \multicolumn{4}{|c|}{ Panicle length $(\mathrm{cm})$} \\
\hline & $P_{1}-$ PBZ 3 ml.m ${ }^{-1}$ & $P_{2}$ - NAA 80 ppm & $\mathbf{P}_{0}$ - Control & Mean \\
\hline$F_{1}$ - Spermidine $0.01 \mathrm{mM}$ & $17.36 \mathrm{~b}$ & $16.16 \mathrm{~b}$ & $13.76 \mathrm{a}$ & 15.76 \\
\hline$F_{2}-$ Spermine $0.1 \mathrm{mM}$ & $17.10 \mathrm{~b}$ & $16.00 \mathrm{~b}$ & $16.30 \mathrm{~b}$ & 16.46 \\
\hline$F_{3}$ - Boron 1.25 g.l-1 & $14.40 \mathrm{a}$ & $15.33 \mathrm{a}$ & $16.50 \mathrm{~b}$ & 15.41 \\
\hline$F_{0}$ - Control & $17.73 b$ & $15.96 b$ & $12.63 \mathrm{a}$ & 15.44 \\
\hline \multirow[t]{2}{*}{ Mean } & $16.64 b$ & $15.86 \mathbf{a}$ & $14.79 \mathbf{a}$ & \\
\hline & F -Test & S.Em \pm & \multicolumn{2}{|c|}{ CD at $(5 \%)$} \\
\hline Factor $\mathbf{F}$ & * & 0.544 & \multicolumn{2}{|c|}{ NS } \\
\hline Factor $\mathbf{P}$ & $*$ & 0.471 & \multicolumn{2}{|c|}{1.384} \\
\hline $\mathbf{F} \times \mathbf{P}$ & * & 0.943 & \multicolumn{2}{|c|}{2.768} \\
\hline
\end{tabular}

Table.2 Effect of flower enhancing plant growth regulators and fruit set improving chemicals on panicle length $(\mathrm{cm})$ of mango $\mathrm{cv}$. Banganpalli 
Table.3 Effect of flower enhancing plant growth regulators and fruit set improving chemicals on

\begin{tabular}{|c|c|c|c|c|}
\hline \multirow{2}{*}{ Treatment } & \multicolumn{4}{|c|}{ Panicle breadth $(\mathrm{cm})$} \\
\hline & $P_{1}-$ PBZ 3 ml.m ${ }^{-1}$ & $P_{2}$ - NAA 80 ppm & $P_{0}$ - Control & Mean \\
\hline$F_{1}$ - Spermidine $0.01 \mathrm{mM}$ & $12.06 \mathrm{~b}$ & $9.866 \mathrm{a}$ & $9.36 \mathrm{a}$ & $10.42 \mathbf{a}$ \\
\hline$F_{2}$ - Spermine $0.1 \mathrm{mM}$ & $12.20 \mathrm{~b}$ & $11.16 \mathrm{~b}$ & $12.46 \mathrm{~b}$ & $11.94 \mathbf{b}$ \\
\hline$F_{3}$ - Boron 1.25g.l-1 & $11.90 \mathrm{~b}$ & $9.93 \mathrm{ba}$ & $11.70 \mathrm{~b}$ & $11.17 \mathbf{a}$ \\
\hline$F_{0}$ - Control & $13.10 \mathrm{c}$ & $11.66 \mathrm{~b}$ & $10.23 \mathrm{a}$ & $11.66 \mathrm{~b}$ \\
\hline \multirow[t]{2}{*}{ Mean } & $12.31 \mathbf{b}$ & $10.65 \mathbf{a}$ & $10.93 \mathbf{a}$ & \\
\hline & F - Test & S.Em \pm & \multicolumn{2}{|c|}{ CD at $(5 \%)$} \\
\hline Factor $\mathbf{F}$ & $*$ & 0.334 & \multicolumn{2}{|c|}{0.981} \\
\hline Factor $\mathbf{P}$ & $*$ & 0.289 & \multicolumn{2}{|c|}{0.849} \\
\hline $\mathbf{F} \times \mathbf{P}$ & $*$ & 0.579 & \multicolumn{2}{|c|}{1.699} \\
\hline
\end{tabular}

panicle breadth $(\mathrm{cm})$ of mango cv. Banganpalli

Table.4 Effect of flower enhancing plant growth regulators and fruit set improving chemicals on

\begin{tabular}{|c|c|c|c|c|c|}
\hline \multirow{2}{*}{ Treatment } & \multicolumn{5}{|c|}{ Days } \\
\hline & $P_{1}-$ PBZ 3 ml.m ${ }^{-1}$ & $\mathbf{P}_{2}-\mathbf{N A A}$ & 80 & $P_{0}-$ Control & Mean \\
\hline$F_{1}$ - Spermidine $0.01 \mathrm{mM}$ & $55.66 \mathrm{~b}$ & $56.00 \mathrm{~b}$ & & $45.66 \mathrm{a}$ & 52.44 \\
\hline$F_{2}$ - Spermine $0.1 \mathrm{mM}$ & $59.66 \mathrm{~b}$ & $48.33 \mathrm{a}$ & & $53.33 \mathrm{~b}$ & 53.77 \\
\hline$F_{3}$ - Boron 1.25 g.l-1 & $58.00 \mathrm{~b}$ & $54.33 \mathrm{~b}$ & & $53.33 b$ & 55.22 \\
\hline$F_{0}$ - Control & $62.00 \mathrm{c}$ & $60.66 \mathrm{c}$ & & $46.33 \mathrm{a}$ & 56.22 \\
\hline \multirow[t]{2}{*}{ Mean } & $58.83 \mathrm{c}$ & $54.83 \mathbf{b}$ & & $49.66 \mathbf{a}$ & \\
\hline & \multicolumn{2}{|l|}{ F- Test } & \multicolumn{2}{|c|}{ S.Em \pm} & CD at $(5 \%)$ \\
\hline Factor $\mathbf{F}$ & \multicolumn{2}{|l|}{$*$} & \multicolumn{2}{|c|}{1.251} & NS \\
\hline Factor $\mathbf{P}$ & \multicolumn{2}{|l|}{$*$} & \multicolumn{2}{|c|}{1.083} & 3.179 \\
\hline $\mathbf{F} \times \mathbf{P}$ & \multicolumn{2}{|l|}{$*$} & \multicolumn{2}{|c|}{2.167} & 6.358 \\
\hline
\end{tabular}

number of days taken for fruit set from panicle initiation of mango cv. Banganpalli

Table.5 Effect of flower enhancing plant growth regulators and fruit set improving chemicals on number of fruit set per panicle of mango cv. Banganpalli

\begin{tabular}{|c|c|c|c|c|c|}
\hline \multirow{2}{*}{ Treatment } & \multicolumn{5}{|c|}{ Fruits in number } \\
\hline & $P_{1}-$ PBZ 3 ml.m ${ }^{-1}$ & $P_{2}-$ NAA & 80 & $P_{0}$ - Control & Mean \\
\hline $\mathrm{F}_{1}$ - Spermidine $0.01 \mathrm{mM}$ & $5.80 \mathrm{~b}$ & $5.60 \mathrm{~b}$ & & $5.53 b$ & $5.64 \mathrm{~b}$ \\
\hline$F_{2}$ - Spermine $0.1 \mathrm{mM}$ & $5.40 \mathrm{~b}$ & $5.20 \mathrm{a}$ & & $5.20 \mathrm{a}$ & $5.26 \mathbf{a}$ \\
\hline$F_{3}$ - Boron 1.25 g.l-1 & $6.40 \mathrm{~d}$ & $5.86 \mathrm{c}$ & & $5.86 \mathrm{c}$ & $6.04 c$ \\
\hline $\mathbf{F}_{0}$ - Control & $6.20 \mathrm{c}$ & $5.80 \mathrm{~b}$ & & $4.86 \mathrm{a}$ & $5.62 \mathrm{~b}$ \\
\hline \multirow[t]{2}{*}{ Mean } & $5.95 \mathrm{c}$ & $5.61 \mathrm{~b}$ & & $5.36 \mathbf{a}$ & \\
\hline & \multicolumn{2}{|l|}{ F - Test } & \multicolumn{2}{|c|}{ S.Em \pm} & CD at $(5 \%)$ \\
\hline Factor $\mathbf{F}$ & \multicolumn{2}{|l|}{$*$} & \multicolumn{2}{|c|}{0.085} & 0.251 \\
\hline Factor $\mathbf{P}$ & \multicolumn{2}{|l|}{$*$} & \multicolumn{2}{|c|}{0.074} & 0.217 \\
\hline $\mathbf{F} \times \mathbf{P}$ & \multicolumn{2}{|l|}{$*$} & \multicolumn{2}{|c|}{0.148} & 0.434 \\
\hline
\end{tabular}


Table.6 Effect of flower enhancing plant growth regulators and fruit set improving chemicals on fruit weight $(\mathrm{gm})$ of mango cv. Banganpalli

\begin{tabular}{|c|c|c|c|c|}
\hline \multirow[b]{2}{*}{ Treatment } & \multicolumn{4}{|c|}{ Fruit weight (g) } \\
\hline & $P_{1}-$ PBZ 3 ml.m ${ }^{-1}$ & $\begin{array}{c}P_{2}-\underset{\text { NAA }}{\text { ppm }} \\
80\end{array}$ & $\mathbf{P}_{0}$ - Control & Mean \\
\hline$F_{1}-$ Spermidine $0.01 \mathrm{mM}$ & $320.00 \mathrm{~b}$ & $318.00 \mathrm{~b}$ & $239.00 \mathrm{a}$ & $289.00 \mathbf{b}$ \\
\hline$F_{2}$ - Spermine $0.1 \mathrm{mM}$ & $284.00 \mathrm{~b}$ & $318.00 \mathrm{~b}$ & $268.00 \mathrm{a}$ & $290.00 \mathbf{b}$ \\
\hline$F_{3}$ - Boron 1.25 g.l-1 & $273.66 \mathrm{a}$ & $331.66 \mathrm{c}$ & $303.33 b$ & $302.88 \mathbf{b}$ \\
\hline$F_{0}$ - Control & $291.33 b$ & $240.66 \mathrm{a}$ & $268.66 \mathrm{a}$ & $266.88 \mathbf{a}$ \\
\hline \multirow[t]{2}{*}{ Mean } & $289.74 \mathbf{a}$ & $302.08 \mathbf{b}$ & \multirow[b]{2}{*}{ S.Em \pm} & \\
\hline & \multicolumn{2}{|l|}{ F - Test } & & CD at (5\%) \\
\hline Factor $\mathbf{F}$ & \multicolumn{2}{|l|}{$*$} & 8.143 & 23.885 \\
\hline Factor $\mathbf{P}$ & \multicolumn{2}{|l|}{$*$} & 7.052 & 20.685 \\
\hline$F \times P$ & \multicolumn{2}{|l|}{$*$} & & 41.370 \\
\hline
\end{tabular}

Table.7 Effect of flower enhancing plant growth regulators and fruit set improving chemicals on yield $(\mathrm{kg})$ of mango cv. Banganpalli

\begin{tabular}{|c|c|c|c|c|}
\hline \multirow[b]{2}{*}{ Treatment } & \multicolumn{4}{|c|}{ Yield (kg.tree-1) } \\
\hline & $P_{1}-$ PBZ 3 ml.m ${ }^{-1}$ & $\begin{array}{c}\mathbf{P}_{2}-\underset{\text { NAA }}{\text { ppm }} \\
80\end{array}$ & $\mathbf{P}_{0}$ - Control & Mean \\
\hline$F_{1}$ - Spermidine $0.01 \mathrm{mM}$ & $50.24 \mathrm{~b}$ & $48.54 \mathrm{~b}$ & $31.38 \mathrm{a}$ & $43.38 \mathbf{b}$ \\
\hline$F_{2}-$ Spermine $0.1 \mathrm{mM}$ & $41.36 \mathrm{~b}$ & $36.88 \mathrm{a}$ & $36.80 \mathrm{a}$ & $38.34 \mathbf{a}$ \\
\hline$F_{3}$ - Boron 1.25 g.l-1 & $36.76 \mathrm{a}$ & $49.19 \mathrm{~b}$ & $42.36 \mathrm{~b}$ & $42.77 \mathbf{b}$ \\
\hline$F_{0}$ - Control & $43.79 \mathrm{~b}$ & $28.36 \mathrm{a}$ & $30.80 \mathrm{a}$ & $34.32 \mathbf{a}$ \\
\hline \multirow[t]{2}{*}{ Mean } & $43.03 \mathbf{b}$ & $40.75 \mathbf{b}$ & $35.33 \mathbf{a}$ & \\
\hline & \multicolumn{2}{|l|}{ F - Test } & S.Em \pm & CD at (5\%) \\
\hline Factor $\mathbf{F}$ & \multicolumn{2}{|l|}{$*$} & 1.893 & 5.552 \\
\hline Factor $\mathbf{P}$ & \multicolumn{2}{|l|}{$*$} & 1.639 & 4.808 \\
\hline $\mathbf{F} \times \mathbf{P}$ & \multicolumn{2}{|l|}{ * } & & 9.617 \\
\hline
\end{tabular}

Table.8 Effect of flower enhancing plant growth regulators and fruit set improving chemicals on number of days taken from panicle initiation to harvesting of mango cv. Banganpalli

\begin{tabular}{|c|c|c|c|c|}
\hline \multirow[b]{2}{*}{ Treatment } & \multicolumn{4}{|c|}{ Days in number } \\
\hline & $P_{1}-$ PBZ 3 ml.m ${ }^{-1}$ & $\begin{array}{c}\mathbf{P}_{2}-\text { NAA } \\
\text { ppm }\end{array}$ & $\mathbf{P}_{0}$ - Control & Mean \\
\hline$F_{1}$ - Spermidine $0.01 \mathrm{mM}$ & $109.00 \mathrm{a}$ & $113.66 \mathrm{a}$ & $121.66 \mathrm{~b}$ & $114.77 \mathbf{a}$ \\
\hline$F_{2}$ - Spermine $0.1 \mathrm{mM}$ & $117.66 \mathrm{~b}$ & $122.33 b$ & $121.33 \mathrm{~b}$ & $120.44 \mathbf{b}$ \\
\hline$F_{3}$ - Boron 1.25 g.l-1 & $116.33 a$ & $120.66 \mathrm{~b}$ & $116.66 \mathrm{a}$ & $117.88 \mathbf{a}$ \\
\hline$F_{0}$ - Control & $127.33 \mathrm{c}$ & $119.66 \mathrm{~b}$ & $131.33 \mathrm{c}$ & $126.10 \mathbf{c}$ \\
\hline \multirow[t]{2}{*}{ Mean } & $117.58 \mathbf{a}$ & $119.07 \mathbf{a}$ & $122.74 \mathbf{b}$ & \\
\hline & \multicolumn{2}{|l|}{ F - Test } & S.Em \pm & CD at $(5 \%)$ \\
\hline Factor $\mathbf{F}$ & \multicolumn{2}{|l|}{ * } & 1.573 & 4.613 \\
\hline Factor $\mathbf{P}$ & \multicolumn{2}{|l|}{$*$} & 1.362 & 3.995 \\
\hline $\mathbf{F} \times \mathbf{P}$ & \multicolumn{2}{|l|}{$*$} & & 7.991 \\
\hline
\end{tabular}


Table.9 Effect of flower enhancing plant growth regulators and fruit set improving chemicals on benefit cost ratio of mango cv. Banganpalli

\begin{tabular}{|c|c|c|c|c|}
\hline \multirow{2}{*}{ Treatment } & \multicolumn{4}{|c|}{ Benefit: Cost } \\
\hline & $P_{1}-\operatorname{PBZ} 3$ ml.m ${ }^{-1}$ & $P_{2}$ - NAA $80 \mathrm{ppm}$ & $P_{0}$ - Control & Mean \\
\hline$F_{1}$ - Spermidine $0.01 \mathrm{mM}$ & 1.82 & 2.71 & 1.35 & 1.96 \\
\hline$F_{2}$ - Spermine $0.1 \mathrm{mM}$ & 0.28 & 0.12 & 0.29 & 0.23 \\
\hline$F_{3}$ - Boron 1.25 g.l-1 & 1.15 & 3.06 & 2.80 & 2.33 \\
\hline$F_{0}$ - Control & 1.97 & 1.33 & 1.53 & 1.54 \\
\hline Mean & 1.30 & 1.80 & 1.53 & \\
\hline
\end{tabular}

Basic cost of cultivation $=30,000$ per ha

Market price of fruits $=$ Rs 30 per kg

Basic cost of Chemicals:

Chemical Rs.

1) $\mathrm{P}_{1}$ - Paclobutrazol $\quad 5,025 / 1$

2) $\mathrm{P}_{2}$-NAA $6,360 / \mathrm{Kg}$

3) $\mathrm{F}_{1}$-Spermidine $\quad 3,018 / \mathrm{gm}$

4) $\mathrm{F}_{2}-$ Spermine $\quad 5,618 / \mathrm{gm}$

$\mathrm{F}_{3}$-Boron 640/Kg

Among fruit set improving chemicals minimum number of days taken from panicle initiation to harvesting was recorded in application of spermidine $\left(\mathrm{F}_{1}\right)$ (114.77), which were on par with application of boron $\left(\mathrm{F}_{3}\right)$ (117.88). Maximum days were recorded in untreated control $\left(\mathrm{F}_{0}\right)(126.10)$, which was on par with application of spermine $\left(\mathrm{F}_{2}\right)$ (120.44). This minimization in number of days taken for harvesting from panicle initiation by boron application is may be due to early fruit set, pollen tube germination and growth (Nyomora and Brown, 1997). Early maturity by polyamines may be due to early fruit set, pollen tube germination and growth cause for early maturity (Amanullah Malik and Zora Singh, 2006). Among interactions minimum number of days taken from panicle initiation to harvesting was recorded in application of paclobutrazol along with spermidine $\left(\mathrm{P}_{1} \mathrm{~F}_{1}\right)$ (109.00), which was on par with application of NAA along with spermidine $\left(\mathrm{P}_{2} \mathrm{~F}_{1}\right)$ (113.66), paclobutrazol along with boron $\left(\mathrm{P}_{1} \mathrm{~F}_{3}\right)$ (116.33) and spraying of boron alone $\left(\mathrm{P}_{0} \mathrm{~F}_{3}\right)$ (116.66). Maximum number of days taken from panicle initiation to harvesting was recorded in control $\left(\mathrm{P}_{0} \mathrm{~F}_{0}\right)$ (131.66). The fruit maturity depends mostly on the available degree days (or) heat units (Shinde et al., 2001) and these early harvesting in paclobutrazol treated trees may be due to delayed fruit set in paclobutrazol treated trees which might have got better exposed to more heat units than other. Early maturity by polyamines may be due to early fruit set, pollen tube germination and growth cause for early maturity. In the interaction of paclobutrazol along with spermidine synergistically minimise the number of days taken for harvesting from panicle initiation may be due to paclobutrazol providing more heat units for maturity and by polyamine early fruit set might have caused for these synergistic minimisation of number of days 
taken for harvesting from panicle initiation. Similar synergistic effect on reducing the days taken for harvesting from panicle initiation was earlier reported by Kumar Raj et al., (2005) in mango. $\mathrm{KH}_{2} \mathrm{PO}_{4}$ along with $\mathrm{H}_{3} \mathrm{PO}_{4}$ application could able to minimise the number of days taken for harvesting from panicle initiation compare to individual application.

The Benefit cost ratio of mango cv. Banganpalli sprayed with different flower enhancing plant growth regulators and fruit set improving chemicals are presented in the table 9. Among the flower enhancing plant growth regulator treatments the highest benefit cost ratio was recorded with application of NAA $\left(\mathrm{P}_{2}\right)(1.80)$, lowest benefit cost ratio was recorded with application of paclobutrazol $\left(\mathrm{P}_{1}\right)$ (1.30). This is due to the low chemical cost per $\mathrm{kg}$ (or) lit and further due to less dosage of NAA compared to the paclobutrazol. Among the fruit set improving chemical treatments the highest benefit cost ratio was recorded with application of boron $\left(\mathrm{F}_{3}\right)$ (2.33), lowest benefit cost ratio was recorded with application of spermine $\left(\mathrm{F}_{2}\right)$ (0.23). This may due to low chemical cost per $\mathrm{kg}$ (or) lit of boron compare to spermine and spermidine. Among the interactions highest benefit cost ratio was recorded in application of NAA along with boron $\left(\mathrm{P}_{2} \mathrm{~F}_{3}\right)$ (3.06), followed by spraying of boron alone $\left(\mathrm{P}_{0} \mathrm{~F}_{3}\right)$ (2.80), NAA along with spermidine application $\left(\mathrm{P}_{2} \mathrm{~F}_{1}\right)$ (2.71) and application of paclobutrazol alone $\left(\mathrm{P}_{1} \mathrm{~F}_{0}\right)$ (1.97). Lowest benefit cost ratio was recorded in application of NAA along with spermine $\left(\mathrm{P}_{2} \mathrm{~F}_{2}\right)(0.12)$. This may be due to chemical cost of per $\mathrm{kg}$ or lit was lesser compare to other chemicals which were used in interactions.

\section{References}

Aman Ullah Malik and Zora Singh. 2006. Improved fruit retention, yield and fruit quality in mango with exogenous application of polyamines. Scientia Horticulturae, 110:167-174.

Anonymous. 2004. Annual Report, Indian Institute of Horticulture Research, Bangalore, http://www.iihr.res.in/PL. PHY.Biochem-hormones.html.

Beyer, E.M.J. 1976. A potent inhibitor of ethylene action in plants. Plant Physiol., 58: 268-271.

Bhagwan, A., Vanajalatha, K., Prabhakar Reddy, I., Sarkar, S. K. and Girwani, A. 2011. Standardization of Dosage and Time of Soil Application of Cultar on Flowering and Yield of Mango cv. Banganpalli. Presented in Global Conference on Augmenting Production and Utilization of Mango: Biotic and Abiotic Stresses held on 21-24th June, 2011 at Lucknow.

Burondkar, M.M. and Gunjate, R.J. 1993. Control of vegetative growth and induction of early and regular cropping in mango with paclobutrazol. Acta Hort., 341: 206-215.

Crisosto, C.H. 1988. Putrescine influences ovule senescence, fertilization time, and fruit set in 'Comice' pear. J. Am. Soc. Hort. Sci., 113: 708-712.

Davenport, T.L. 2007. Reproductive physiology of mango. Braz. J. Plant Physiol., 19(4): 363-376.

Davenport, T.L. 2003. Management of flowering in three tropical and subtropical fruit tree species. HortSci., 38: 1331-1335.

Enas, A.M., Ali, S. M., Sarrwy, A. and Hassan, H.S.A. 2010. Improving Canino Apricot Trees Productivity by Foliar Spraying with Polyamines. J. Appl. Sci. Res., 6(9): 1359-1365.

Fraga, M.F. 2004. Changes in polyamine concentration associated with aging in Pinus radiata and Prunus persica. Tree Physiol., 24: 1221-1226.

Galston, A.W. 1983. Polyamines as modulators of plant development. 
BioSci., 33: 382-388.

GoGuey, T. 1990. The effects of repeated application of cultar (Paclobutrazol) to Mangifera indica L. Var. Valencia. Fruits (Paris), 45(6): 599-607.

Kachru, R.B., Singh, R.N. and Chacko, E.K. 1971. Inhibition of flowering in mango by gibberellic acid. Horticulture Sci., 6: 140-141.

Kumar Raj, M., Reddy, Y.N., Chandrasekhar, R. and Srihari, D. 2005. Effect of foliar application of chemicals and plant growth regulators on flowering of unpruned mango trees of cv. Baneshan. J. Res. ANGRAU, 33(2): 6-11.

Kumbhar, A.R., Gunjate, R.T. and Amim, S. M. 2007. Comparision of cultar and austar as source of paclobutrazol for flowering and fruiting in Kesar in Mango. Acta Hort. 820, Proc. 8th Int. Mango symposium.

Malik, A.U. and Singh, Z. 2004. Endogenous free polyamines of mangos in relation to development and ripening. J. Am. Soc. Hort. Sci., 129: 280-286.

Moti Singh, A.S., Chaudhary, A.S. and Prasad, M. 1987. A note on the effect of some plant regulators on fruit retention in mango (Mangifera indica L). Haryana J. Hort. Sci., 15(3/4): 221 (Hort. Abst. 51 (3):2200).

Muhammad Nafees, Muhammad Faqeer, Saeed Ahmad, Mueen Alam Khan, Moazzam Jamil, and Muhammad Naveed Aslam. 2010. Paclobutrazol soil drenching suppresses vegetative growth, reduces malformation, and increases production in mango. Int. J. Fruit Sci., 10: 431-440.

NHB. 2011. National Horticulture Board, Guargon, India. http://www.gov.in/area production. html.

Nyomora, A.M.S. and Brown, P.H. 1997. Fall foliar-applied boron increases tissue boron concentration and nut set of almond. J. Amer. Soc. Hort. Sci. 122(3):
405-410.

Orwintinee chusri, Naoko koza, Tatsushi ogata, Hirokazu higuchi, and Yoshimi yonemoto. 2008. Application of paclobutrazol for flowering and fruit production of Irwin mango (Mangifera indica L.) in Okinawa. Trop. Agr. Develop., 52(3): 69-73.

Pandey, S., Ranade, S.A., nagar, P.K. and kumar, N. 2000. Role of polyamines and ethylene as modulators of plant senescence. J. Biosci., 25: 291-299.

Panse and Sukhatme. 1985. Statistical methods for agricultural workers. ICAR New Delhi.

Ponce, M.T., Guinazu, M. and Tizio, R. 2002. Effect of putrescine on embryo development in the stenospermocarpic grape cvs Emperatriz and Fantasy. Vitis, 41: 53-54.

Quinlin, J.D. and Richardson, P.J. 1984. Effect of Paclobutrazol on apple shoot growth. Acta Horticulture, 146: 105110.

Ramzy, G., Stino Habashy, S.A. and Kelani, R.A. 2011. Productivity and fruit quality of three mango cultivars in relation to foliar spray of calcium, zinc, boron and potassium. J. Horticultaral Sci. Ornamenta plant, 3(2): 91-98.

Saleh, M.M. and El-Monem, E.A. 2003. Improving the productivity of Fagri Kalan mango trees grown under sandy soil conditions using potassium, boron and sucrose as foliar spray. Ann. Agric. Sci., 48L: 747-756.

Sanna Ebeed and Abd El-Migeed, M.M.M. 2005. Effect of Spraying Sucrose and Some Nutrient Elements on Fagri Kalan Mango Trees. J. Appl. Sci. Res., 1(5): 341-346.

Shinde, A.K., Burondkar, M.M., Bhingrade, R.T., Waghmare, G.M., Rangwala, A.D. and Wagh, R.G. 2001. Heat unit requirement for fruit maturity in mango varieties. Indian J. Plant Physiol., 6(2): 
194-196.

Shiozaki, S., Ogata, T. and Horiuchi, S. 2000. Endogenous polyamines in the pericarp and seed of the grape berry during development and ripening. Sci. Hort., 83: 33-41.

Singh, Z. and Dhillon, B.S. 1992. Effect of paclobutrazol on floral malformation, yield and quality of mango (Mangifera indica L.). Acta Horticulturae, 296: 5154.

Vijayalakshmi, D. and Srinivasan, P.S. 1998. Induction of flowering in off year mango cv. Alphonso as influenced by chemicals and growth regulators. Ann. Plant Physiol., 12(2): 93-97.

Wahdan, M.T., Habib, S.E,. Bassal, M.A. and Qaoud, E.M. 2011. Effect of some chemicals on growth, fruiting, yield and fruit quality of "Succary Abiad" mango cv. J. American Sci., 7(2): 651-658.

Winston, E.C. 1992. Evaluation of paclobutrazol on growth, flowering and yield of mango cv. Kensington pride. Australian J. Experimental Agri., 32(1): 97-104.

Wolukau, J.N., Zhang, S.L., Xu, G.H. and Chen, D. 2004. The effect of temperature, polyamines and polyamine synthesis inhibitor on in vitro pollen germination and pollen tube growth of Prunus mume. Sci. Hort., 99: 289-299.

Zong Runi and Dong, R. 2000. Effect of boron on blossom, Embryo development and yield of mango. $J$. Yunnan Agric. University, 15: 63-65.

\section{How to cite this article:}

Golla Vijay Krishna, A. Bhagwa, M. Raj Kumar and Siva Shankar, A. 2017. Flowering and Production Improvement Studies of Mango cv. Banganpalli in Relation to Plant Growth Regulators and Chemicals. Int.J.Curr.Microbiol.App.Sci. 6(8): 481-493. doi: https://doi.org/10.20546/ijcmas.2017.608.063 